Proceedings of the XXIII Conference on Applied Crystallography, Krynica Zdrój, Poland, September 20-24, 2015

\title{
Microstructure and Residual Stress in AMS 6308 Steel after Vacuum Carburizing and Gas Quenching
}

\author{
K. Dychtoñ*, P. Kocurek, P. Rokicki, B. Wierzba, M. Drajewicz and J. Sieniawski \\ Department of Material Science, Rzeszów University of Technology, \\ Powstanców Warszawy 12, 35-959 Rzeszów, Poland
}

\begin{abstract}
In this work, the vacuum carburizing and gas quenching has been done on gears box made of high strength alloy steel AMS 6308 in four different temperatures. The measurements of hardness was done to evaluate the effective case depth for each temperature. The analysis of retained austenite was presented as a factor which can affect values of residual stress. The residual stresses were measured in Protoi XDR portable diffractometer and the analysis was examined to find influence of temperature and carburizing time on the direction and values of residual stresses.
\end{abstract}

DOI: 10.12693/APhysPolA.130.953

PACS/topics: 81.05.-t, 87.64.--t, 83.85.-c

\section{Introduction}

The application of vacuum carburizing and gas quenching processes has gained significant importance in the aerospace industry. Increase of the temperature of carburizing process and using gas quenching lead to economic benefits like reduction in duration time, energy consumption, and environmental protection.

The main assets of vacuum carburizing are shortening time of process, absence of external oxidation, high efficiency and reproducibility, power saving and ecological safety. Another attractive benefit of the carburization process is the compressive residual stresses development at the surface [1]. Vacuum carburizing occurs in the self-regulation mode consisting of cyclic intervals of saturation and diffusion [2]. Mathematic models of the process connected with numerical simulations are the basic tool for controlling the carburization process $[3,4]$. Carbon case hardening can be employed to achieve a wide range of effective case depths in a wide range of steels [5]. The carburized case in the load-carrying components is necessary to ensure wear resistance and high fatigue strength [6]. Used in aerospace heavily loaded gears are commonly manufactured from high strength and case hardened alloy steels such as AMS 6308 (Pyrowear 53) [7]. The surface durability and fatigue resistance in this steel are enhanced by the compressive residual stresses generated at the surface after combination of carburization and hardening processes [8]. Importance of knowing the value of residual stresses result from fact that the presence of the residual stresses influences on the fatigue strength of case hardened components [9].

The X-ray diffraction (XRD) stress measurement is non-destructive method for analysis the failure reasons. A constant improvement of X-ray diffractometers and the perpetual development of the plane-stress residual

\footnotetext{
*corresponding author; e-mail: kdychton@prz.edu.pl
}

stress model enable for measuring stress in the hardened steels [10]. XRD measurements can be applied to materials with fine grained structure which produce a diffraction peak of adequate intensity, non-affected by interference in the high back-reflection regions [11].

In this paper the influence of carburizing temperature on the magnitude and direction of the residual stresses will be analysed for AMS 6308 steel. The carburization time was changed due to the temperature to ensure effective case depth in the range of $0.9-1.2 \mathrm{~mm}$. Additionally the change in the microstructure of the carburized case with the temperature changes will be presented. The analysis of retained austenite was presented as a factor which can affect values of residual stress. The aim of the article was to analyse the influence of carburizing temperature on the case properties, especially the magnitude and direction of the residual stresses.

\section{Experimental}

The gears of alloy steel AMS 6308 was investigated. They were carburized, quenched, and tempered. The temperature of austenitization and tempering was the same for every process while temperature for carburizing was changed in the range of $925-1050{ }^{\circ} \mathrm{C}$. After carburization, the gears were austenitized in the temperature lower than $925^{\circ} \mathrm{C}$ and quenched in the inert gas - nitrogen. The subzero treatment was done after quenching. The tempering was done in the temperature lower than $200^{\circ} \mathrm{C}$ in the nitrogen. Saturation and diffusion times for carburization were computed by numerical simulation of the mass diffusion mathematic model based on Darken approximation [3]. The vacuum carburizing followed by quenching and tempering was carried out to achieve $0.9-1.2 \mathrm{~mm}$ effective case depth for each temperature. The carburized case depth was measured by the use of microhardness tester. Elastic deformation and retained austenite was determined using Protoi XRD portable diffractometer. To calculate internal stresses $\sin ^{2} \Psi$ method was applied with assistance 
of Win2.0 XRD software. Cr $K_{\alpha}$ radiation of $0.2287 \mathrm{~nm}$ wavelength was used due to the radiation source of $20 \mathrm{kV}$, $4 \mathrm{~mA}$ with a beam diameter of $2 \mathrm{~mm}$. The diffraction line $\{211\}$ of martensite phase was analysed for residual stresses at the surface. The quantity of retained austenite was measured for the diffraction lines $\{200\},\{211\}$ of martensite and $\{220\},\{200\}$ of austenite phases.

\section{Results and discussion}

In Fig. 1 the hardness profiles were measured on the cross-section of gear tooth in the pitch line direction. The effective case depth was defined at $513 \mathrm{Hv}$, Table I. The values of effective case depth for temperature 925, 975, 1000 , and $1050{ }^{\circ} \mathrm{C}$ were achieved in the expected range 0.9-1.2 $\mathrm{mm}$. Moreover, increase of the carburizing temperature causes decrease of the total carburizing time, Table I. The martensite phase with the retained austenite regions have been observed on microstructures. For

TABLE I

Comparison of effective case depth in different temperatures.

\begin{tabular}{c|c|c|c|c}
\hline \hline Sample & $\begin{array}{c}\text { Effective } \\
\text { case depth } \\
{[\mathrm{mm}]}\end{array}$ & $\begin{array}{c}\text { Surface } \\
\text { hardness } \\
{[\mathrm{Hv}]}\end{array}$ & $\begin{array}{c}\text { Time of } \\
\text { saturation } \\
{[\mathrm{s}]}\end{array}$ & $\begin{array}{c}\text { Time of } \\
\text { diffusion } \\
{[\mathrm{s}]}\end{array}$ \\
\hline $925^{\circ} \mathrm{C}$ & 0.909 & 812 & 1215 & 28820 \\
$975{ }^{\circ} \mathrm{C}$ & 0.913 & 806 & 990 & 26640 \\
$1000^{\circ} \mathrm{C}$ & 1.000 & 806 & 930 & 25200 \\
$1050^{\circ} \mathrm{C}$ & 1.223 & 780 & 690 & 16500
\end{tabular}

TABLE II

Residual stress for pitch line case carburized tooth.

\begin{tabular}{c|c|c|c|c}
\hline \hline Temp. & $\begin{array}{c}\text { Residual } \\
\text { stress in } \\
y \text { axis } \\
{[\mathrm{MPa}]}\end{array}$ & $\begin{array}{c}\text { Deviation } \\
+/- \\
{[\mathrm{MPa}]}\end{array}$ & $\begin{array}{c}\text { Residual } \\
\text { stress in } \\
x \text { axis } \\
{[\mathrm{MPa}]}\end{array}$ & $\begin{array}{c}\text { Deviation } \\
+/- \\
{[\mathrm{MPa}]}\end{array}$ \\
\hline $925^{\circ} \mathrm{C}$ & -60 & 15 & -86 & 13 \\
$9755^{\circ} \mathrm{C}$ & -546 & 10 & -519 & 15 \\
$1000^{\circ} \mathrm{C}$ & -667 & 23 & -530 & 6 \\
$1050^{\circ} \mathrm{C}$ & -77 & 10 & -33 & 21
\end{tabular}

TABLE III

Retained austenite in material.

\begin{tabular}{c|c|c}
\hline \hline Temperature & $\begin{array}{c}\text { Retained } \\
\text { austenite [\%] }\end{array}$ & $\begin{array}{c}\text { Deviation }+/- \\
{[\%]}\end{array}$ \\
\hline $925^{\circ} \mathrm{C}$ & 5.79 & 0.81 \\
$975^{\circ} \mathrm{C}$ & 5.70 & 0.51 \\
$1000^{\circ} \mathrm{C}$ & 6.84 & 0.79 \\
$1050^{\circ} \mathrm{C}$ & 12.27 & 0.44
\end{tabular}

the temperature $1050{ }^{\circ} \mathrm{C}$ the amount of retained austenite is approximately $12 \%$ and is twice bigger than for other temperatures whose values are presented in Table II. For the temperature $925^{\circ} \mathrm{C}$ the net of carbides occurs at the surface and can affect the residual stress [11]. For temperatures 975 and $1000{ }^{\circ} \mathrm{C}$ the amount of retained austenite is approximately $6 \%$. The small value of compressive residual stresses for temperature $1050{ }^{\circ} \mathrm{C}$ at the surface can be explained by bigger effective case depth and larger amount of retained austenite [11]. For each temperature the residual stresses are compressive which is presented in Table III.

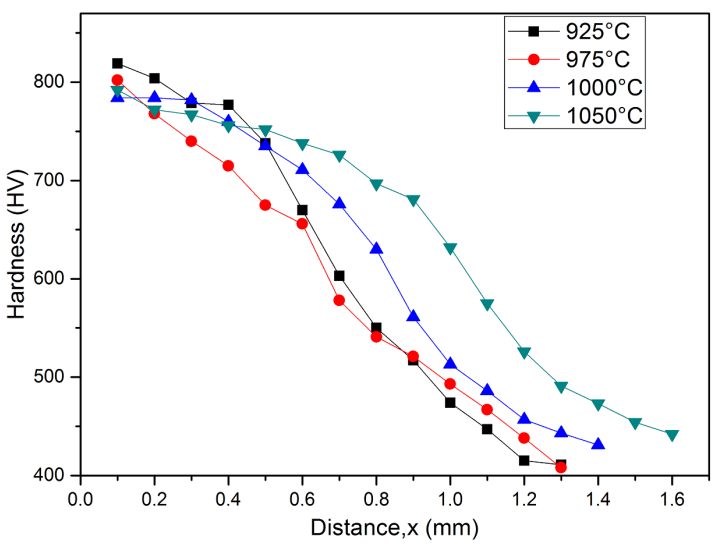

Fig. 1. Hardness profile for each carburizing temperature measured in the pitch line direction on the teeth gear.

\section{Conclusions}

Figure 2 illustrates microstructure of the carburized case for each temperature. Changing the temperature of carburizing causes increase in the effective case depth from $0.909 \mathrm{~mm}$ at the $925^{\circ} \mathrm{C}$ to the $1.223 \mathrm{~mm}$ at the $1050^{\circ} \mathrm{C}$. In the same time the value of retained austenite was doubled from 6 to $12 \%$. Residual stresses measured for each temperature are compressive. Changing carburizing temperature from $925^{\circ} \mathrm{C}$ to $1000{ }^{\circ} \mathrm{C}$ increases ten times the value of compressive residual stress. Values of compressive stresses measured at $925^{\circ} \mathrm{C}$ and $1050{ }^{\circ} \mathrm{C}$ are the same.

a)
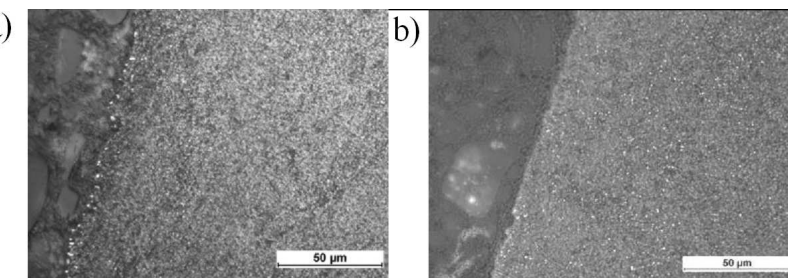

c)

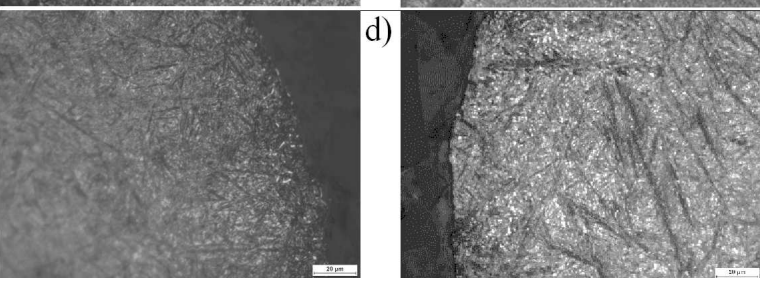

Fig. 2. Microstructures of case hardened gears in different carburizing temperatures: (a) $925^{\circ} \mathrm{C}$, (b) $975^{\circ} \mathrm{C}$, (c) $1000^{\circ} \mathrm{C}$, (d) $1050{ }^{\circ} \mathrm{C}$. 


\section{Acknowledgments}

The research was conducted within the scope of the Applied Research Field PBS1/A5/23/2012 financed by The National Centre for Research and Development (Narodowe Centrum Badań i Rozwoju).

\section{References}

[1] R. LeMaster, B. Boggs, J. Bunn, C. Hubbard, T. Watkins, Am. Gear Manufact. Assoc. 65, 42 (2009).

[2] N.M. Ryzhov, R.S. Fakhurtdinov, A.E. Smirnov, L.P. Fomina, Met. Sci. Heat Treatm 52, 260 (2010).

[3] B. Wierzba, J. Romanowska, M. Zagula-Yavorska, J. Markowski, J. Sieniawski, High Temp. Mater. Process 34, 495 (2015).

[4] K. Dychton, P. Rokicki, A. Nowotnik, M. Drajewicz, J. Sieniawski, Solid State Phenom 227, 425 (2015).
[5] G. Parrish, Carburizing: Microstructures and Properties, ASM International, Ohio 1999.

[6] A.V. Rodionoy, N.M. Ryzhov, R.S. Fakhurtdinov, E.N. Zhidkov, Met. Sci. Heat Treatm 33, 522 (1991).

[7] A. Freborg, B. Ferguson, Z. Li, in: 6th Int. Conf. on Quenching and Control of Distortion, ASM International, 2012, p. 22.

[8] T. Reti, Handbook of Residual Stress and Deformation of Steel, ASM International, Ohio 2002, p. 189.

[9] K. Palaniradja, N. Alagumurthi, V. Soundararajan, Open Mater. Sci. J 4, 92 (2010).

[10] P.S. Prevéy, Developments in Materials Characterization Technologies, ASM International, Ohio 1996, p. 103.

[11] P.S. Prevéy, Residual Stress in Design, Process and Materials Selection, ASM International, 1987, p. 19. 